ÇOMÜ Uluslararası Sosyal Bilimler Dergisi 2(4), 1-15, 2017

COMU International Journal of Social Sciences 2(4), 1-15, 2017

\title{
Algılanan Örgütsel Politika, İşyeri Yalnızlığı ve İçsellik Statüsü ilişkisinde Politik Yeteneğin Rolü: Kamu Çalışanları Üzerine Bir Araştırma
}

Şeyda Nur SEÇKIN*

Öz

Bu çalışmada, algılanan örgütsel politika, işyeri yalnızlığı ve içsellik statüsü ilişkisi ile bu ilişkide politik yeteneğin düzenleyici rolünün incelenmesi amaçlanmaktadır. Yapılan literatür taramasında söz konusu değişkenler arasındaki ilişkiyi ele alan herhangi bir çalışmaya rastlanmamış; elde edilecek bulguların ilgili yazına katkı sağlayabileceği varsayımından hareketle saha araştırmasının yapılmasına karar verilmiştir.Yapılan analizler sonucunda, algılanan örgütsel politikanın işyeri yalnızlığını pozitif; içsellik statüsünü de negatif yönde etkilediği görülmüştür. Bunun yanı sıra, işyeri yalnızıı̆ının algılanan örgütsel politika-içsellik statüsü ilişkisinde aracılık etkisinin olduğu tespit edilmiştir. Bir diğer ifadeyle, algılanan örgütsel politika arttıkça işyeri yalnızlığı da artmakta; işyeri yalnızlığının artmasıyla birlikte katılımcıların içsellik statüsü (örgüte olan aidiyet duyguları) azalmaktadır. Politik yeteneği düşük olan katılımcıların ise algıladıkları örgütsel politika arttkç̧a daha fazla sosyal anlamda yalnızlaşttkları ve içsellik statülerinin de daha fazla zayıfladığı tespit edilmiştir.

Anahtar Kelimeler: Algılanan Örgütsel Politika, Işyeri Yalnızlığı, Içsellik Statüsü, Politik Yetenek

\section{The Role of Political Skill on Perceived Organizational Politics, Workplace Loneliness and Insider Status: A Research on Public Employees}

\begin{abstract}
In this study it is aimed to determine perceived organizational politics, workplace loneliness and insider status relationship and the role of political skill on this relationship. During the international and domestic literature review, it has not been come across to any research investigating these relationships. With the assumption that study findings can make contribution to relevant area, it was decided to conduct the field research. Research results indicate that perceived organizational politics has a positive impact on workplace loneliness and negative impact on perceived insider status. Moreover it was found that perceived organizational politics-insider status relationship is mediated by workplace loneliness. In other words; as perceived organizational politics increase, workplace loneliness also increases and with the increase of workplace loneliness, perceived insider status declines. Beside this, it was found that participants with low political skill become more socially alone and their internal status declines more with the increase of perceived organizational politics.
\end{abstract}

Keywords: Perceived Organizational Politics, Workplace Loneliness, Insider Status, Political Skill.

Yrd.Doç.Dr. Şeyda Nur Seçkin, İnönü Üniversitesi, Yönetim ve Organizasyon A.B.D., seydaseckin@gmail.com 


\section{GíRiş}

Örgüt içinde algılanan politik faaliyetler çalışanların hem işe hem de örgüte yönelik tutum ve davranışlarını olumsuz yönde etkilemekte; aynı zamanda da örgüt içindeki insan ilişkilerinin kalitesini belirlemektedir. Örgüt içi politik faaliyetler hemen hemen tüm çaışanlar tarafindan olumsuz karşılanmakta; aynı zamanda da çalışanlar nezdinde örgüte yönelik güvensizliği de tetiklemektedir. İşgörenler, çalıştıkları kurumu politik olarak algıladıkları takdirde, örgütün eşitlik ve adalet ilkelerine bağıı olarak faaliyet gösterdiğine ilişkin inançları zayıflamakta (Ferris ve Kacmar, 1992:93); açık vermekten kaçınmakta, diğer çalışanları yakından takip ederek açık aramakta (Yang, 2008:88); bir diğer ifadeyle, örgüt içindeki insan ilişkileri kalitesi ve örgütsel iletişim olumsuz yönde etkilenmektedir (Voyer, 1994).

Örgütsel politika algısının çalışanların tutum ve davranışlarını önemli ölçüde biçimlendirmesi ve buradan da örgütsel çıktılara etki etmesi sebebiyle yerli ve yabancı yazında sayısı günden güne artan araştırmaların yapıldığı görülmektedir.Ancak yapılan yerli ve yabancı literatür taramasında algılanan örgütsel politika, işyeri yalnızlığı ve içsellik statüsü ilişkisini; ve bu ilişkide politik yeteneğin rolünü inceleyen herhangi bir çalışmaya rastlanmamıştır. Araştırma konusunun ilgili alana katkı yapacağı düşünülerek saha araştırmasının yapılmasına karar verilmiş; bir devlet üniversitesinde görev yapmakta olan 212 idari personel üzerinde anket çalışması gerçekleştirilmiştir.

\section{KURAMSAL ÇERÇEVE}

\section{1. Örgütsel Politika ve İçsellik Statüsü Algısı}

Örgütsel politika; örgüt üyelerinin kişisel çıkarları doğrultusunda sergiledikleri politik davranışlar bütünü olarak tanımlanabilir (Andrews ve Kacmar, 2001:348). Diğer insanların davranışlarını etkilemeye, olayların seyrini değiştirmeye ve insanların başka koşullarda yapmayacakları şeyleri yapmalarını sağlamaya yönelik sergilenen davranışlar örgütlerdeki politik faaliyetleri oluşturmaktadır (Pfeffer, 1999:41). Nitekim, politik faaliyetler özü itibariyle diğer insanları etki altnna alma girişimleri olup; mevcut çıkarları muhafaza etmek veya daha da artırmak amacıyla sergilenmekte; sergilenen tüm bu davranış ve faaliyetler de örgütleri politik kurumlar haline getirmektedir (Kacmar ve Carlson, 1997)

Örgüt içi politik faaliyetler hemen hemen tüm çalışanlar nezdinde belirsizlik, adaletsizlik, rekabet ve güç mücadelelerini bünyesinde barındıran olumsuz bir durum olarak algılanmaktadır (Kimura, 2013:590). İşgörenler, çalıştıkları kurumu politik olarak algıladıkları takdirde; örgütün eşitlik ve adalet ilkelerine bağlı olarak faaliyet gösterdiğine ilişkin inançları zayıflamakta; örgüte duyulan güvensizlik de artmaktadır (Ferris ve Kacmar, 1992:93). Bunun yanı sıra, algılanan örgütsel politika, çalışanların örgütsel çevre üzerinde sahip olduklarını düşündükleri kontrol duygusunu azaltmakta ve politik faaliyetler çalışanlar tarafindan örgütteki hem mevcut hem de gelecekteki pozisyonlarına ilişkin bir tehdit unsuru olarak algılanmaktadır (Ferris vd., 1989). Dolayısıyla da, örgütlerde iş görenler açık vermekten kaçınmakta, diğer çalışanları yakından takip etmekte ve başkalarının kusur ve hatalarını yakalama eğilimi göstermektedir (Yang, 2008:88).

Poon (2003:138)'a göre, örgütsel politikanın yoğun olduğu pek çok örgütte zaman ve enerji kaybı görülmekte; bilgi paylaşımı sınılı hale gelmekte; örgüt üyeleri arasında görünmez bariyerler oluşarak çalışanların örgüte ve işe yönelik tutumları da olumsuz yön- 
de etkilenmektedir. Yapılan araştırmalar örgütün çalışanlar nezdinde politik olarak değerlendirilmesi halinde; çalışanlarda iş stresi (Ferris vd., 1996; Kacmar vd., 1999; Poon, 2003); tükenmişlik (Cropanzano vd., 1997); iş tatminsizliği (Kacmar vd.,1999; Witt vd., 2000; Poon, 2003) ve işten ayrılma niyetinin arttğını göstermektedir (Kacmar vd., 1999; Maslyn ve Fedor, 1998; Poon, 2003). Bunun yanı sıra, çalışanların örgütsel vatandaşlık (Vigoda, 2000), örgütsel bağlılık (Drory 1993; Nye ve Witt 1993; Maslyn ve Fedor 1998; Witt 1998; Vigoda 2000; Vigoda-Gadot vd., 2003) düzeyleri ile iş performansları da azalmaktadır (Allen vd., 1979; Gandz ve Murray, 1980; Aksoy, 2016; Madison vd., 1980; Ferris ve Kacmar, 1992; Parker vd.,1995; Kacmar ve Baron, 1999; Valle ve Perrewe, 2000; O'Connor ve Morrison, 2001; Adams vd., 2002).

Algılanan örgütsel politika, çalışanların kendilerini örgütten psikolojik olarak çekmeleri ile de sonuçlanabilmektedir. Cropanzano vd. (1997) araştırma sonuçları, çalıştıkları kurumu politik olarak nitelendiren bireylerin psikolojik olarak kendilerini politik çevreden yalıtmayı tercih ettiklerini göstermektedir. İş sırasında hayal kurma, iş dışı sohbetler, telefon görüşmeleri ile çalışanlar mevcut politik ortamdan ve örgütten kendilerini soyutlama yoluna başvurabilmektedirler. Harris vd. (2005:30)'a göre ise, politik ortam bazı çaışanlara işten ayrılmaktan başka bir alternatif bırakmamaktadır. Hali hazırda iş stresi ve gerginlik yaşayan çalışanlar çalıştıkları kurumu bir de politik olarak algıladıklarında, işten ayrılma niyetleri daha da artmaktadır. Çünkü çalıştıkları kurum, yaşadıkları iş stresiyle mücadele etmede kendilerine yardımcı olmak bir kenara; yaşadıkları sıkıntıların daha da artmasına sebep olmaktadır. Dolayısıyla da algılanan örgütsel politikanın çalışanlarda işten ayrılma niyetini tetiklediği görülmektedir.

Örgüt içi politik faaliyetlerin pek çok çalışan nezdinde nahoş bir durum olarak nitelendirilmesi ve örgüt içinde güvensizliği tetiklemesi sebebiyle çalışanların örgütsel politika algısı arttıkça örgüte karşı hissettikleri adiyet duygularının da (algılanan içsellik statüsü) azalacağı ifade edilebilir. Algılanan örgüt içi politik faaliyetler, çalışanlar tarafindan bir stres faktörü olarak değerlendirilip örgütsel çevreye ilişkin belirsizliği de tetiklediğinden (Goodman vd., 2011); çalışanların örgüte yaptıkları katkıların örgüt nezdinde takdir ve değer göreceğine ilişkin inançlarının da zayıflayacağı söylenebilir. Sosyal Mübadele Kuramı (Blau, 1964) uyarınca; örgütle ekonomik olduğu kadar sosyal mübadele ilişkisi içinde de olan çalışanların örgüte duydukları güvenin azalmasından dolayı örgüt içi politik faaliyetlerin çalışanların örgütle kendileri aralarında duygusal bir bağ kurmalarını; kendilerini kurumun bir parçası olarak hissetmelerini (bir diğer ifadeyle, algıladıkları içsellik statüsünü) olumsuz yönde etkileyeceği ifade edilebilir. Buradan hareketle geliştirilen hipotez aşağıdaki gibidir:

H1: Algılanan örgütsel politika, içsellik statüsü algısını negatif yönde etkiler.

\section{2. Örgütsel Politika ve İçsellik Statüsü iliş̧kisinde Çalışan Yalnızlığııın Aracılık Rolü}

Yalnızlık; bir kişinin diğer insanlarla nicelik veya nitelik bakımından tatmin edici ilişki ve etkileşimlerden yoksun olması sonucu içinde bulunduğu psikolojik durum olarak tanımlanabilir (Lam ve Lau, 2012, Wright vd., 2006; Wright, 2005). Peplau ve Perlman (1984); yalnızlığın sosyal izolasyondan farklı bir kavram olduğunu belirtmekte ve kişinin arzu ettiği ile hali hazırda sahip olduğu insan ilişkileri arasındaki uyuşmazlık sonucu yalnızlığın ortaya çıktığına dikkat çekmektedir. Birey nezdinde algılanan bu uyuşmazlık, bilişsel bir 
değerlendirme olup kişinin beklentilerine, sahip olduğu değer ve ilkelere göre şekillenmekte; dolayısıyla da kişiden kişiye göre değişmektedir.

Yalnızlık kavramına ilişkin ilk sınıflandırma Weiss (1973) tarafindan yapılmış; duygusal ve sosyal yalnızlık olmak üzere iki kategoride ele alınmıştır. Duygusal yalnızlık; bireyin bir başka kişiyle yakın ilişkiden mahrum olması biçiminde tanımlanırken; sosyal yalnızlık, kişinin nicelik olarak ilişki ağlarından, ortak ilgi alanlarına sahip bir arkadaş grubu veya sosyal ağdan yoksun olma durumu olarak ifade edilmiştir (Russell vd., 1984). Wright ve arkadaşları (2006) da; genel yalnızlık kavramına ilişkin bu tipolojiden yola çıkarak işyeri yalnızlığını duygusal yoksunluk ve sosyal arkadaşlık olmak üzere iki kategoride ele alarak kavramsallaştırmıştır. Duygusal yalnızlık, bireyin işyerinde sahip olduğu ilişkilerin duygusal anlamda kalitesine (bir diğer ifadeyle, niteliğine) ilişkin algısı olarak tanımlanırken; sosyal arkadaşlık boyutu da çalışanın söz konusu ilişkilerin niceliksel yönüne ilişkin değerlendirmesi olarak ifade edilmiştir.

Yapılan araştırmalar işyeri yalnızlığının çalışanların hem yaptıkları işe hem de örgüte yönelik tutum ve davranışlarını olumsuz yönde etkilediğini işaret etmektedir. İşyerinde algılanan yalnızlık arttıkça çalışanlarda iş performansı (Steinburg vd., 1999); duygusal bağlıık (Özçelik ve Barsade, 2011) ve örgütsel vatandaşıı davranışları azalmaktadır (Keser ve Karaduman, 2014) . Bunun yanı sıra, işyerindeki yalnızlığın lider üye ilişki kalitesini zedelediği (Lam ve Lau, 2012); işkoliklik (Karakaya vd., 2015) ve işten ayrılma niyeti (Kaymaz vd., 2014) ile de pozitif yönde ilişkili olduğu görülmektedir.

Wright (2005)'e göre, her ne kadar örgütler sosyal yapılar olarak çalışanlara diğer insanlarla iletişim kurma, sosyal bağlantılar edinme gibi bir takım firsatlar sunsa da; bu durum her zaman için örgütlerde sağ|ıklı ve tatminkar insan ilişkilerinin var olduğu anlamına gelmemektedir. İnsan ilişkilerinin son derece yoğun olduğu iş ortamlarında bile insanların kendilerini yalnız hissettikleri sıklıkla görülmektedir. Bunun bir sebebi de; çalışma ortamlarının özünde rekabetçi bir yapıya sahip olması; dolaysıyla da samimi ve tatminkar sosyal ilişkilerin kurulmasının zorlaşmasıdır. Araştırmacıya göre, iş yeri yalnızlı̆ının oluşumu ve gelişiminde kişilik özelikleri ve bireyin iletişim becerilerindeki yetersizlikler her ne kadar etkili olsa da; iş yeri yalnızlığına yol açan örgütsel faktörler; bilhassa da örgütün psiko-sosyal yapısı göz ardı edilmektedir. Nitekim yapılan araştırmalar; örgütlerde korku iklimi (Wright, 2005); istismarcı yönetim (Ay, 2015) ve örgütsel sessizliğin (Nartgün ve Demirer, 2016) işyeri yalnızlı̆̆ı ile pozitif; etik liderlik davranışları (Eroğluer ve Yılmaz, 2015) ve destekleyici örgüt ikliminin (Erdil ve Ertosun, 2011) de negatif yönde ilişkili olduğunu göstermektedir.

İşyeri yalnızlığına pozitif yönde etki eden örgütsel çevreye ilişkin faktörlerden birisinin de algılanan örgütsel politika olduğu düşünülmektedir. Algılanan örgüt içi politik faaliyetlerin örgüt üyeleri arasında rekabet, güvensizlik ve şüpheciliği tetiklemesi (Yang, 2008) ve çalışanlar arasında görünmez bariyerler oluşturarak iletişimi olumsuz yönde etkilemesi (Poon, 2003) nedeniyle çalışanların hem nicelik hem de nitelik olarak işyerindeki mevcut ilişkilerinden daha az tatmin olacağı; bir diğer ifadeyle daha fazla sosyal ve duygusal anlamda yalnızlık hissedebilecekleri ifade edilebilir. Bunun yanı sıra, örgüt içindeki politik faaliyetler çalışanlar nezdinde bir tehdit unsuru olarak algılandığından (Ferris vd., 1989) çalışanların kendilerini korumak adına bilinçli bir şekilde hem psikolojik hem de fiziksel olarak geride durmayı tercih edebilecekleri de düşünülebilir. Nitekim, Cropanzano vd. (1997) araştırma sonuçları, çalıştkları kurumu politik olarak nitelendiren bireylerin 
kendilerini mevcut politik ortamdan yalıtmayı tercih ettiklerini; hayal kurma, internette gezinme veya telefon görüşmeleri ile örgütsel çevreden soyutlanma eğiliminde olduklarını göstermektedir. Dolayısıyla, algılanan örgütsel politikanın; kurumdaki birlik ruhunu zedeleyeceği; bireyler arası ilişki kalitesini düşüreceği; dolayısıyla da işyeri yalnızlığına pozitif yönde etki edebileceği söylenebilir. Buradan yola çıkarak geliştirilen hipotezler aşağıdaki gibidir:

H2: Algılanan örgütsel politika, duygusal yalnızlığı pozitif yönde etkiler.

H3: Algılanan örgütsel politika, sosyal yalnızlığı pozitif yönde etkiler.

Ashforth ve Mael (1989), işyerindeki tatminkar olmayan ilişkilerin çalışanların örgütle duygusal bağ kurmalarını güçleştirdiğini beirtmektedir. Diğer örgüt üyeleri ile hem sosyal hem de duygusal anlamda sağlıklı ve tatminkar ilişkilere sahip olmayan çalışanların kuruma yönelik daha az aidiyet hissedeceği; bir diğer ifadeyle içsellik statüsü algılarının da daha az olacağı ifade edilebilir. Bunun yanı sıra, yalnızlığın bireyleri diğer insanlara karşı daha şüpheci yaklaşmaya (Ernst ve Cacioppo, 1999); insan ilişkilerinde zarar görmemek adına daha kaçınmacı ve korunmacı bir tavır almaya sevk ettiği de dile getirilmektedir (Lam ve Lau, 2012). Dolayısıyla, algılanan örgütsel politika arttkça çalışanların kendilerini hem sosyal hem de duygusal anlamda daha yalnız hissedecekleri; artan yalnızıkla beraber de daha şüpheci ve kaçınmacı bir tavır alacakları; böylelikle de içsellik statüsü algılarının (örgüte olan aidiyet duygularının) azalacağı ifade edilebilir. Buradan yola çıkarak geliştirilen hipotezler aşağıdaki gibidir:

H4: Duygusal yalnızlık, algılanan örgütsel politika ve içsellik statüsü ilişkisinde aracılık etkisine sahiptir.

H5: Sosyal yalnızlık, algılanan örgütsel politika ve içsellik statüsü ilişkisinde aracılık etkisine sahiptir.

\section{3. Örgütsel Politika, Çalışan Yalnızlığı ve Algılanan İçsellik Statüsü ílişkisinde Politik Yeteneğin Düzenleyici Rolü}

Politik yetenek, diğer insanları anlama ve onları etkileyecek biçimde hareket edebilme kabiliyeti olarak tanımlanabilir. Poltik yetenek; sosyal beceriklilik, kişiler arası etki, network yeteneği ve içtenlik olmak üzere dört boyuttan oluşmaktadır. Sosyal beceriklilik; sosyal etkileşimleri kolayca kavrama olarak tanımlanırken; kişilerarası etki boyutu da esneklik ve diğer insanları kolayca etki altnna alma kabiliyeti olarak ifade edilmektedir. İçtenlik boyutu ise kişinin samimi ve güvenilir olduğuna dair bir izlenim bırakma yetisi olup network yeteneği boyutu da diğer insanlarla kolayca ilişki ağları kurma ve bu ilişki ağlarını geliştirme kabiliyeti olarak tanımlanmaktadır(Ferris vd., 2005:7-12),

Ferris vd. (2005:127) ise politik yeteneği, kişinin diğer insanları etkili bir şekilde anlayıp, bu anlayışı bireysel veya örgütsel amaçları gerçekleştirmek üzere diğer insanları etkilemede kullanması olarak ifade etmektedir. Politik yetiye sahip kişiler, değişen durumlara göre hareket ve davranışlarını adapte etmekte; bunu yaparken de karşı tarafta son derece içten, samimi, destekleyici ve güvenilir bir insan olduklarına dair bir intiba bırakabilmektedirler.

Yapılan araştırmalar politik yeteneğin duygusal zeka (Meisler, 2014); kariyer başarıSı (Perrewe ve Nelson, 2004); iş performansı, iş tatmini ve örgütsel bağlılık (Munyon 
vd.,2015) ile pozitif yönde ilişkili olduğunu göstermektedir. Politik yeteneği yüksek bireyler, işyerinde diğer insanlarla daha az çatışma yaşarken; dışlanma ve kötü muamele ile de daha az karşı karşıya kalmaktadırlar (Cullen vd., 2014). Bunun yanı sıra, bu kişilerin işyerindeki negatif insan ilişkileri ve sosyal etkileşimleri kariyer ilerlemelerine yönelik bir tehdit unsuru olarak değerlendirmedikleri de ifade edilmektedir. Dolaysıyla da, örgüt içindeki belirsizlik,çatş̧ma, adaletsizlik gibi sosyal stres faktörlerinden daha az olumsuz yönde etkilenmektedirler (Harvey vd., 2007; Meurs vd., 2010).

Politik yeteneği yüksek bireylerin politik yetenekten yoksun olan bireylere kıyasla politik bir örgütsel çevreye adapte olma ve yönetmede daha becerikli oldukları söylenebilir. Insan ilişkilerinde başarılı olmaları sebebiyle hem kendilerine olan güvenlerinin daha fazla olduğu hem de içinde bulundukları sosyal çevrede kendilerini edilgen değil etken gördükleri; dolayısıyla da örgütsel çevrede sahip oldukları kontrol duygularının da daha fazla olduğu ifade edilebilir (Ferris vd., 2007)

Ferris vd. (1989); çalışanların iş çevrelerini kavrama (anlama) ve çevreleri üzerinde sahip olduklarını düşündükleri kontrol duygusunun artmasıyla beraber örgütsel politikadan daha az olumsuz yönde etkilendiklerine dikkat çekmektedir. Örgütte cereyan eden olayları neden sonuç ilişkisinde görebilen; ilişki ağlarını doğru okuyabilen ve mevcut duruma kolayca adapte olabilen çalışanlar, örgüt içi politikadan daha az olumsuz yönde etkilenmektedirler. Bu sebeple, politik yeteneği yüksek bireylerin örgütsel politika ile daha etkili bir şekilde yüzleşebildikleri ve daha rahat başa çıkabildikleri görülmektedir (Kimura, 2013:591).

Dolayısıyla, algılanan örgütsel politikanın işyeri yalnızlığı üzerindeki olumsuz etkisinin çalışanların sahip olduğu politik yeteneğin düzeyine göre farklılaşabileceği söylenebilir. Politik yeteneği yüksek çalışanların, sosyal etkileşimleri kolayca kavramaları, esneklikleri ve diğer insanları etkileme kabiliyetleri nedeniyle örgüt içi politikadan daha az olumsuz yönde etkilenecekleri; böylelikle de daha az sosyal ve duygusal yalnızlık yaşayabilecekleri söylenebilir. Politik yeteneği düşük bireylerin ise mevcut politik ortamla başa çıkmada daha fazla zorlanacakları; dolayısıyla da daha fazla korunmacı ve kaçınmacı bir duruş sergileyerek sosyal ve duygusal anlamda daha fazla yalnızlaşacakları ifade edilebilir. Buradan yola çıkarak geliştirilen hipotezler aşağıdaki gibidir:

H6: Politik yetenek, algılanan örgütsel politika ve duygusal yalnızlık ilişkisinde düzenleyici rol oynar.

H7: Politik yetenek, algılanan örgütsel politika ve sosyal yalnızlık ilişkisinde düzenleyici rol oynar.

\section{METEDOLOJi}

\subsection{Araştırma Yöntemi ve Örneklem}

Saha araştırması; bir devlet üniversitesinde görev yapan idari personel üzerinde yürütülmüştür. Araştırma yöntemi nicel araştırma olup; veri toplama aracı olarak anket çalışması gerçekleştirilmiştir. Hazırlanan anket formları katılımcılara elektronik posta yoluyla ulaştırılmıştır. Kolayda örneklem yöntemi kullanılmış; 234 katılımcıdan geri dönüş sağlanmıştır. Ancak anketlerin bir kısmının eksik ve/veya hatalı doldurulması sebebiyle 212 adet anket değerlendirmeye alınmıştır. Elde edilen veriler, güvenilirlik, doğrulayıcı faktör analizi, korelasyon ve regresyon analizleri yapılarak incelenmiş; araştrma hipotez- 
leri PROCESS Macro 2.16 kullanılarak test edilmiştir.

Örnekleme ilişkin tanımlayıcı istatistiklere baktı̆ımızda; katılımcıların \%11,5'inin 24-29; \%32,7'sinin de 30-34 yaş aralığında olduğu görülmektedir. Bir diğer ifadeyle, katılımclların yarıya yakın bir kısmının (\%44,2); 35 yaşın altında olduğu ifade edilebilir. 35-39 yaş aralığında olan katılımcıların oranı \%20,5; 40-44 yaş aralığında olan katilımcıların oranı $\% 16 ; 45-49$ yaş aralığında olanların oranı ise $\% 10,9$ 'dur. 50 yaş ve üstü olan katılımcıların oranı ise \%8,3'tür. Katilımcıların yarıdan fazlası erkek (\%68,6) ve evlidir (\%54,8). \%11,2'si lise; 22,8'i ön lisans; \%62,4'ü lisans; \%3,6'sı da lisansüstü mezunu olduğunu belirtmiştir. Katılımcıların çalışma sürelerine baktığımızda ise \%21,8'inin 3 yıldan az; \%35,9'unun 3-8 yıl; \%16,7'sinin 9-14; \%25,6'sının da 15 yıl ve üzeri bir süredir mevcut işlerinde çalıştkları görülmektedir.

\subsection{Kullanılan Ölçekler}

İşyeri yalnızlığının ölçümünde Wright vd. (2006) tarafindan geliştirilen ölçek kullanılmıştr. Ölçek duygusal yoksunluk (9 madde) ve sosyal arkadaşlık (7 madde) olmak üzere iki boyuttan oluşmaktadır. Ölçeğin Türkçeye uyarlaması Doğan vd. (2009) tarafindan yapılmış; Türkiye örnekleminde geçerli ve güvenilir olduğu tespit edilmiştir. Algılanan örgütsel politika için; Kacmar ve Ferris (1991) tarafindan üç boyutlu olarak geliştirilen ancak Nye ve Witt (1993)'in 1297 askeri personel üzerinde yürüttüğü araştırma sonucunda tek boyutlu olduğu görülen 12 maddelik algılanan örgütsel politika ölçeği kullanılmıştır. Politik yeteneğin ölçümünde Ahearn ve arkadaşları (2004) tarafindan geliştirilen tek boyutlu ve 6 maddeden oluşan politik yetenek ölçeği; içsellik statüsü için de Stamper ve Masterson'ın (2002) geliştirmiş olduğu 6 maddelik ölçek kullanılmıştır. Tüm ölçekler 5'li Likert olup ölçek ifadelerine ilişkin yanıtlar 1=Kesinlikle Katılmıyorum; 2=Katılmıyorum; 3=Kararsızım; 4=Katılıyorum; 5=Kesinlikle Katılıyorum şeklinde derecelendirilmiştir.

Yapılan doğrulayıcı faktör analizi sonucunda işyeri yalnızlığı ölçeğinin ki-kare istatistiğinin serbestlik derecesine oranı ( $\mathrm{X} 2 / \mathrm{df}$ ) 1,999; kök ortalama kare yaklaşım hatası (RMSEA) 0,080; Tucker-Lewis indeks (TLI) değeri 0,937 ve karşılaştırmalı uyum indeks (CFI) değeri de 0,952 olarak bulunmuştur. Dolayısıyla işyeri yalnızlığı ölçeğinin iki boyutlu faktör yapısının yeterli uyum değerlerini sağladığı ifade edilebilir. Algılanan örgütsel politika ve içsellik statüsü ölçeklerine ilişkin elde edilen değerler ise sırasıyla; algılanan örgütsel politika için $\chi 2 / d f=1,501 ; R M S E A=0,057 ; T L I=0,984$ ve $C F I=0,991 ;$ içsellik statüsü için de $\chi 2 / d f=0,859 ; R M S E A=0,010 ; T L I=0,999$ ve $C F I=0,999$ 'dür. Son olarak, politik yetenek ölçeğinin ki-kare istatistiğinin serbestlik derecesine oranı ( $\chi 2 / d f) 1,982 ;$ kök ortalama kare yaklaşım hatası (RMSEA) 0,067; Tucker-Lewis indeks (TLI) değeri 0,969 ve karşılaştırmalı uyum indeks (CFI) değeri de 0,986 olarak bulunmuştur. Elde edilen sonuçlar algılanan örgütsel politika, içsellik statüsü ve politik yetenek ölçeklerinin tek boyutlu faktör yapılarının yeterli uyum değerlerini sağladığına işaret etmektedir. Kullanılan ölçeklere ilişkin Cronbach $\alpha$ değerleri ise; algılanan örgütsel politika için 0,907; içsellik statüsü için 0,920; politik yetenek için de 0,872'dir. İşyeri yalnızlı̆̆ının alt boyutlarına ilişkin Cronbach $\alpha$ değerleri ise duygusal yoksunluk için 0,907 ; sosyal arkadaşlık için de 0,895 olarak elde edilmiştir. 


\subsection{Araştırma Modeli ve Hipotezler}

Kuram ve araştırma bulgularından yola çıkılarak geliştirilen araştırma modeli ve hipotezler aşağıdaki gibidir:

\section{Şekil 1: Araştırma Modeli}

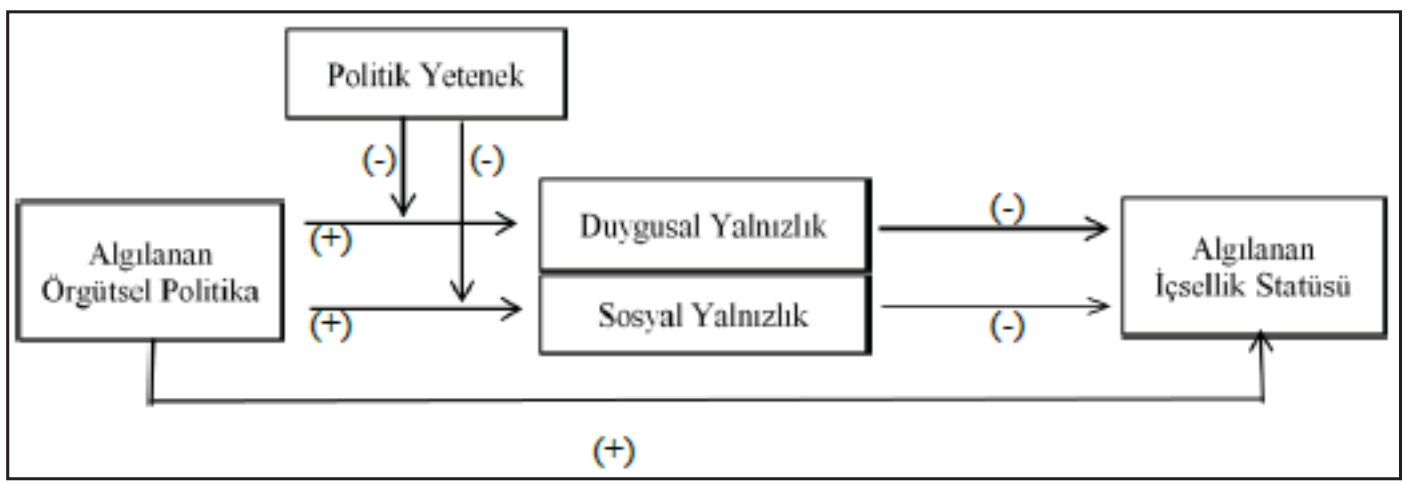

\section{H1: Algılanan örgütsel politika, içsellik statüsünü negatif yönde etkiler.}

H2: Algılanan örgütsel politika, duygusal yalnızlığı pozitif yönde etkiler.

H3: Algılanan örgütsel politika, sosyal yalnızlığı pozitif yönde etkiler.

H4: Duygusal yalnızlık, algılanan örgütsel politika ve içsellik statüsü ilişkisinde aracılık etkisine sahiptir.

H5: Sosyal yalnızlık, algılanan örgütsel politika ve içsellik statüsü ilişkisinde aracılık etkisine sahiptir.

H6: Politik yetenek, algılanan örgütsel politika ve duygusal yalnızlık ilişkisinde düzenleyici rol oynar.

H7: Politik yetenek, algılanan örgütsel politika ve sosyal yalnızlık ilişkisinde düzenleyici rol oynar.

\subsection{Bulgular}

Değişkenlere ilişkin aritmetik ortalama, standart sapma değerleri ile korelasyon katsayıları Tablo 1'de yer almaktadır.

Tablo 1'de yer alan aritmetik ortalamalara baktığımızda, algılanan örgütsel politika, içsellik statüsü ve politik yetenek düzeylerine ilişkin değerlerin orta seviyelerde olduğu görülmektedir. Katılımcıların duygusal ve sosyal yalnızık düzeyleri, ortalamanın altında olup duygusal yalnızık, sosyal yalnızlık düzeyine kıyasla daha yüksektir. Değişkenlere ilişkin korelasyon katsayılarını incelediğimizde ise; algılanan örgütsel politikanın içsellik statüsü ile negatif ( $r=-, 493 ; p=0,000)$; duygusal ve sosyal yalnızlık ile de pozitif yönde ilişkili olduğu görülmektedir (sırasıyla; $r=, 742 ; r=, 426 ; p<0,01$ ). Bunun yanı sıra, politik yeteneğin hem duygusal hem de sosyal yalnızlık ile negatif yönde ilişkili olduğu (sırasıyla; r=-,434; r=-,714; $p<0,01$ ) ancak sosyal yalnızlık ile olan ilişkisinin daha güçlü olduğu görülmektedir. 
Tablo 1: Değişkenlere İlişkin Korelasyon Tablosu

\begin{tabular}{|c|c|c|c|c|c|c|c|}
\hline Değiş̧kenler & Ort. & SS & 1 & 2 & 3 & 4 & 5 \\
\hline $\begin{array}{l}\text { 1.Algılanan } \\
\text { örgütsel politika }\end{array}$ & 3,377 & 0,915 & - & & & & \\
\hline 2.i̇çsellik statüsü & 3,589 & 0,952 &,$- 493 * * *$ & - & & & \\
\hline 3.Duygusal yalnızlık & 2,855 & 0,959 &, $742 * *$ &,$- 658^{* *}$ & - & & \\
\hline 4.Sosyal yalnızlık & 2,367 & 0,871 &, $426 * *$ &,$- 701 * *$ &, $589 * *$ & - & \\
\hline 5.Politik yetenek & 3,482 & 0,828 &,$- 199 *$ &, $646 * *$ &,$- 434 * *$ &,$- 714 * *$ & - \\
\hline
\end{tabular}

Araştırma hipotezlerini test etmek üzere regresyon analizi gerçekleştirilmiş; katılımcılara ilişkin demografik değişkenler kontrol grubu olarak belirlenmiştir. Bunun yanı sıra, politik yeteneğin; algılanan örgütsel politika-duygusal yalnızlık ile algılanan örgütsel politika-sosyal yalnızlık arasında düzenleyici bir etkiye sahip olup olmadığını belirlemek üzere etkileşim terimleri oluşturulmuş ve analize dahil edilmiştir. Elde edilen sonuçlar Tablo 2'deki gibidir:

Tablo 2. Hiyerarşik Regresyon Analizi Sonuçları

\begin{tabular}{|c|c|c|c|}
\hline & $\begin{array}{l}\text { Duygusal Yalnızlık } \\
\beta \text { (S.H) }\end{array}$ & $\begin{array}{l}\text { Sosyal Yalnızlık } \\
\beta(\text { S.H) }\end{array}$ & $\begin{array}{l}\text { İçsellik Statüsü } \\
\beta(S . H)\end{array}$ \\
\hline Sabit & $-1,778(, 242)$ &,$- 086(, 321)$ &,$- 375(, 267)$ \\
\hline Yaş & ,135(,045) &,$- 012(, 089)$ & ,123(,074) \\
\hline Cinsiyet &, $044(, 102)$ &,$- 026(, 162)$ &,$- 054(, 134)$ \\
\hline Medeni Durum &,$- 059(, 042)$ & ,039(,027) & ,061(,059) \\
\hline Eğitim &,$- 032(, 084)$ &, $115(, 112)$ &, $007(, 082)$ \\
\hline Çalışma Süresi &,$- 093(, 074)$ &,$- 185(, 099)$ & ,026(,093) \\
\hline$R^{2} / \Delta R^{2}$ & ,039/0,039 & ,071/,071 & ,045/,045 \\
\hline Algılanan Örgütsel Politika &, $737(, 054)^{* * *}$ &, $409(, 073)^{* * *}$ &,$- 482 /(, 074)^{* * *}$ \\
\hline$R^{2} / \Delta R^{2}$ & ,565/,526 & ,233/,162 & ,270/,225 \\
\hline Duygusal Yalnızlık & & &,$- 400(, 088)^{* * *}$ \\
\hline Sosyal Yalnızlık & & &,$- 462(, 073)^{* * *}$ \\
\hline$R^{2} / \Delta R^{2}$ & & & ,605/,335 \\
\hline $\begin{array}{l}\text { Algılanan Örgütsel } \\
\text { PolitikaXPolitikYetenek }\end{array}$ &,$- 031(, 046)$ &,$- 223(, 044)^{* * *}$ & \\
\hline$\Delta \mathrm{R}^{2}$ & ,0011 & ,058 & \\
\hline
\end{tabular}


Tablo 2'de yer alan regresyon katsayılarına baktığımızda; katılımcılara ilişkin demografik değişkenlerin sosyal ve duygusal yalnızlık ile içsellik statüsü üzerinde anlamlı bir etkiye sahip olmadığı görülmektedir. Algılanan örgütsel politikanın içsellik satüsünü negatif ( $\beta=-$ ,482; $p<0,001$ ); duygusal ve sosyal yalnızlığı da pozitif yönde etkilediği görülmektedir (sırasıyla; $\beta=, 737 ; p<0,001 ; \beta=, 409 ; p<0,001)$. Dolayısıyla; $H 1, H 2$, ve H3 hipotezleri desteklenmektedir. Bunun yanı sıra, hem duygusal hem de sosyal yalnızlığın içsellik statüsünü negatif yönde etkilediği görülmektedir (sırasıyla; $\beta=-, 400 ; p<0,001 ; \beta=-, 462 ; p<0,001$ ).

Duygusal ve sosyal yalnızlığın; algılanan örgütsel politika-içsellik statüsü ilişkisinde aracılık etkisine sahip olup olmadığı PROCESS Macro 2.16 Model 4 aracılığıyla incelenmiş ve bootstrapping yöntemi kullanılmıştır. Elde edilen sonuçlara göre, hem duygusal hem de sosyal yalnızlığın algılanan örgütsel politika - içsellik statüsü ilişkisinde aracılık etkisinin anlamlı olduğu tespit edilmiştir [(Duygusal Yalnızlık: $\mathrm{Cl}=\% 95$; BootLLCl= -,6999; Boo$\mathrm{tULCl}=-, 3497$; Boot SE=,0895); (Sosyal Yalnızlık: Cl= \%95; BootLLCl= -,3767, BootULCl= -,1306; Boot SE=,0634)]. Böylelikle, H4 ve H5 hipotezleri desteklenmiştir.

Politik yeteneğin; algılanan örgütsel politika-duygusal yalnızlık ile algılanan örgütsel politika-sosyal yalnızlık arasında düzenleyici bir etkiye sahip olmadığını belirlemek üzere oluşturulan etkileşim terimlerinin anlamlılığına baktığımızda ise; politik yeteneğin sadece algılanan örgütsel politika-sosyal yalnızlık arasında olası bir düzenleyici bir etkiye sahip olduğu görülmektedir $(\beta=-, 223 ; p<0,001)$. Politik yeteneğin; algılanan örgütsel politika-duygusal yalnızlık arasında ise düzenleyici etkisinin istatistiki açıdan anlamlı olmadığı tespit edilmiştir ( $\beta=-, 031 ; p>0,05)$. Dolayısıyla, $\mathrm{H} 6$ hipotezi reddedilmektedir.

Algılanan örgütsel politikanın sosyal yalnızlıkla olan ilişkisinin büyük ölçüde politik yeteneğe bağlı olup olmadığını belirlemek üzere basit eğim testi (Aiken ve West, 1991) yapılmış; politik yeteneğin +1SS ve -1SS değerlerinde regresyon katsayıları hesaplanmıştır. Elde edilen sonuçlara göre; politik yeteneği düşük olan çalışanlarda, algılanan örgütsel politikanın sosyal yalnızlık üzerindeki etkisi pozitif yönde iken $(\beta=, 494 ; p<, 001)$; politik yeteneği yüksek olan çalışanlarda ise algılanan örgütsel politikanın sosyal yalnızlık üzerinde anlamlı bir etkisinin olmadığı görülmüştür $(\beta=, 037 ; p=0,597)$. Böylelikle; H7 hipotezi kısmen desteklenmektedir.

Algılanan örgütsel politikanın sosyal yalnızlık aracılığıyla içsellik statüsü üzerindeki dolaylı etkisi ve bu etkide politik yeteneğin düzenleyici rolü PROCESS Macro 2.16 Model 7 kullanılarak incelenmiştir. Elde edilen sonuçlar Tablo 4'te yer almaktadır:

Tablo 3: Algılanan Örgütsel Politikanın Sosyal Yalnızlık Aracılığıyla Algılanan İçsellik Statüsü Üzerindeki Dolaylı Etkisi

\begin{tabular}{llll} 
Politik Yetenek & Dolaylı Etki & $\begin{array}{l}\text { Algılanan İçsellik Statüsü } \\
\text { Bootstrap Cl=\%95 } \\
\text { Boot LLCI }\end{array}$ & BootULCI \\
\hline Çok Düşük &,- 1773 &,- 3377 &,- 0467 \\
Düşük &,- 1125 &,- 2181 &,- 0297 \\
Orta &,- 0606 &,- 1374 &,- 0133 \\
Yüksek &,- 0346 &,- 1042 &, 0086 \\
Çok Yüksek &,- 0087 &,- 0718 &, 0533
\end{tabular}


Elde edilen sonuçlar değerlendirildiğinde katılımcıların politik yetenekleri çok düşükten orta seviyelere kadar yükseldikçe; örgüt içindeki politik faaliyetlerin sosyal yalnızlık düzeyleri üzerindeki olumsuz etkisinin azaldığı; bu olumsuz etkinin azalmasıyla beraber içsellik statülerinin de (örgüte olan aidiyet duygularının) daha az olumsuz yönde etkilendiği görülmektedir. Ancak katılımcıların yüksek veya çok yüksek seviyede politik yeteneğe sahip olmaları halinde; algılanan örgütsel politikanın sosyal yalnızlık aracılığıyla içsellik statüsü üzerindeki dolaylı etkisinin istatistiki açıdan anlamlı olmadığı görülmektedir.

\section{SONUÇ}

Elde edilen bulgular, algılanan örgütsel politikanın katilımcıların duygusal ve sosyal yalnızık düzeylerini pozitif; içsellik statüsü algılarını da negatif yönde etkilediğini göstermektedir. Bunun yanı sıra, duygusal ve sosyal yalnızlığın algılanan örgütsel politika-içsellik statüsü ilişkisinde aracılık etkisine sahip olduğu görülmektedir. Bir diğer ifadeyle, algılanan örgütsel politika arttıkça katılımcıların hem sosyal hem de duygusal açıdan yalnızlaştıkları; sosyal ve duygusal yalnızlık arttıkça da içsellik statülerinin (örgüte olan aidiyet duygularının) azaldığı görülmektedir.

Politik yeteneğin düzenleyici rolünü incelediğimizde ise; anlamlı etkinin sadece algılanan örgütsel politika-sosyal yalnızık arasında olduğu görülmektedir. Buna göre, politik yeteneği düşük olan katlımcıların örgüt içindeki politik faaliyetler arttıkça sosyal yalnızlık düzeyleri daha fazla artmaktadır. Politik yeteneği yüksek olan çalışanlarda ise böyle bir etki görülmemektedir. Elde edilen bu sonuç; politik yeteneği yüksek bireylerin sosyal etkileşimleri kolayca kavramaları ve insan ilişkilerindeki esneklikleri nedeniyle örgüt içi politikayla daha rahat başa çıkabildikleri dolayısıyla da örgüt içindeki politik faaliyetler artsa bile bu durumun sosyal yalnızlık düzeylerinde anlamlı bir farklılaşmaya yol açmadığı şeklinde yorumlanabilir.

Bunun yanı sıra, katılımcıların politik yetenekleri çok düşükten orta seviyelere kadar yükseldikçe; örgüt içindeki politik faaliyetlerin sosyal yalnızlık düzeyleri üzerindeki olumsuz etkisinin azaldığı; bu olumsuz etkinin azalmasıyla birlikte içsellik statülerinin de (örgüte olan aidiyet duygularının) daha az olumsuz yönde etkilendiği görülmektedir.

Elde edilen bulgular değerlendirildiğinde; örgüt içinde algılanan politik faaliyetler arttkça katılımcıların hem duygusal hem de sosyal anlamda yalnızlaştıkları; artan yalnızlaşmayla birlikte içsellik statüsü algılarının (örgüte olan aidyet duygularının) da zayıfladığı görülmektedir. Algılanan örgüt içi politik faaliyetlerin bu olumsuz etkisinin bilhassa da politik yeteneği düşük olan çalışanlarda daha belirgin olduğu ifade edilebilir. Bu kişilerin; politik manevra kabiliyetine sahip olmamaları nedeniyle; mevcut politik ortamı kendileri için daha fazla bir tehdit unsuru olarak gördükleri; dolayısıyla da kendilerini korumak adına geriye çekildikleri böylelikle de hem sosyal anlamda daha fazla yalnızlaştıkları hem de aidiyet duygularının da daha fazla zayıfladığı söylenebilir.

Örgüt içinde algılanan politik faaliyetler, çalışanların hem işe hem de örgüte yönelik tutum ve davranışlarını etkilemekte; aynı zamanda da örgüt içindeki insan ilişkilerinin kalitesini belirlemektedir. Algılanan örgütsel politika hemen hemen tüm çalışanlar tarafindan olumsuz karşılanmakta; aynı zamanda da çalışanlar nezdinde örgüte yönelik güvensizliği de tetiklemektedir. Dolayısıyla, örgütlerde politik davranış ve faaliyetlere geçit verilmemesi ve örgütün çalışanlar nezdinde politik olarak algılanıp algılanmadığına 
da dikkat edilmesi gerektiği ifade edilebilir. Örgütlerde, tüm süreç ve faaliyetlere ilişkin açık, net ve kesin kurallar belirlenmesi ve bu kuralların harfiyen yürürlüğe konulmasının önemli olduğu söylenebilir. Böylelikle, hem örgüt içindeki politik faaliyetlerin oluşmasının bir nebze de olsa önüne geçilebileceği hem de örgütün çalışanlar nezdinde politik olarak algılanmasının önemli ölçüde engellenebileceği ifade edilebilir. Bunun yanı sıra, örgütlerde etik kodların oluşturulması, çalışanların örgüt içinde arzu edilen ve edilmeyen davranış ve faaliyetlere ilişkin bilgilendirilip bilinçlendirilmesi ve etkin bir denetim mekanizması kurularak etik kod ve politikaların kurum içinde yerleşiklik kazanmasına çalışılması önerilebilir.

Yapılan literatür taramasında araştırma konusunu ele alan herhangi bir çalışmaya rastlanmadığından elde edilen bulguların ilgili alana katkı sağlayacağı ifade edilebilir. Ancak araştırmanın bir takım kısıtları bulunmaktadır. Bu çalışma, kesitsel bir araştırma olup değişkenler arasında herhangi bir neden-sonuç ilişkisi kurulamamaktadır. Bunun yanı sıra, katılımcıların sosyal beğenilirlik kaygısıyla anket sorularını cevaplandırmış olabilecekleri de bir diğer olası kısıttır. Son olarak, saha araştırması, sadece bir devlet üniversitesinde görev yapan idari personel üzerinde yürütüldügünden; elde edilen bulgular genelleştirilememektedir. Konuya ilişkin bundan sonra yapılacak çalışmalarda; algılanan içsellik statüsü üzerinde etkisi olabileceği düşünülen lider-üye ilişki kalitesi ile birey-örgüt uyumunun araştırma modeline dahil edilmesi konuya daha geniş bir perspektif kazandırması açısından araştırmacılara önerilebilir. 


\section{KAYNAKÇA}

Adams G.L., Ammeter A.P., Treadway D.C., Ferris G.R., Hochwarter W.A., Kolodinsky R.W (2002). Perceptions of organizational politics: additional thoughts, reactions, and multi-level issues. Research in MultiLevel Issues, Vol. 1, pp. 287-94.

Ahearn, K. K., Ferris, G. R., Hochwarter, W. A., Douglas, C., Ammeter, A. P.(2004). Leader Political Skill and Team Performance. Journal of Management, Vol.30, No.3, 309-327.

Aiken, L. S., West, S.G.(1991). Multiple regression: Testing and interpreting interactions. Newbury Park:Sage.

Aksoy, A.(2016). Algılanan Örgütsel Politikanın Bağlamsal Performans Üzerine Etkisi: TRB1 Bölgesi İmalat Sektörü Üzerine Bir Araştırma. Akademik Sosyal Araştırmalar Dergisi, Yıl.4, Sayı.33, 51-60.

Allen R.W., Madison D.L., Porter L.W., Renwick P.A., Mayes B.T. (1979). Organizational politics tactics and characteristics of its actors. California Management Review, Vol. 22, pp. 77-83.

Andrews M. C., Kacmar M. K.(2001). Discriminating among organizational politics, justice, and support. Journal of Organizational Behavior, Vol.22, 347-366.

Ashforth, B. E., Mael, F.(1989). Social Identity Theory and the Organization. Academy of Management Review, Vol.14, 20-39.

Ay, F. A.(2015). İstismarcı Yönetim, İşyeri Yalnızlığı ve Örgütsel Sinizm Arasındaki illişkiler: Sağılı Çalışanlarına Yönelik Bir Çalışma. Uluslararası Sosyal Araştırmalar Dergisi, Cilt.8, Sayı.41, 1116-1126.

Blau, P.(1964). Exchange and power in social life. New York: Free Press.

Cropanzano, R., Howes, J.C., Grandey, A.A. and Toth, P. (1997). The relationship of organizational politics and support to work behaviors, attitudes, and stress. Journal of Organizational Behavior, Vol. 18, 159180.

Cullen, K. L., Fan, J., Liku, C.(20149. Employee Popularity Mediates the Relationship Between Political Skill and Workplace Interpersonal Mistreatment. Journal of Management, Vol.40, No.6, 1760-1778.

Doğan, T., Çetin, B., Sungur, M. Z.(2009). İş Yaşamında Yalnızlık Ölçeği Türkçe formunun geçerlilik ve güvenilirlik çalışması. Anadolu Psikiyatri Dergisi, Cilt.10, 271-277.

Drory A. (1993). Perceived political climate and job attitudes. Organization Studies, Vol.14, 59-71.

Erdil, O., Ertosun, Ö. G.(2011). The Relationship between Social Climate and Loneliness in the Workplace and Effects on Employee Well-Being. Procedia Social and Behavioral Sciences, Vol.24, 505-525.

Ernst, J. M., Cacioppo, J.T.(1999). Lonely Hearts: Psychological Perspectives on Loneliness. Applied and Preventive Psychology, Vol8, 1-22.

Eroğluer, K., Yılmaz, Ö.(2015). Etik Liderlik Davranışlarının Algılanan Örgüt İklimi Üzerine Etkisine Yönelik Bir Uygulama: İş Yaşamında Yalnızlık Duygusunun Aracılık Etkisi. İşletme Araştırmaları Dergisi, Cilt.7, No.1, 280-308.

Ferris G. R., Russ G. S., Fandt P. M. (1989). Politics in organizations. In Giacalone R. A., Rosenfeld P. (Edts.), Impression Management in Organizations, (pp.143-170), Hillsdale, NJ: Erlbaum

Ferris G. R., Frink D. D., Galang M. C., Zhou J., Kacmar K. M., Howard J. L. (1996). Perceptions of organizational politics: Predictions, stress-related implications, and outcomes. Human Relations, Vol.49, 233-266.

Ferris G.R., Kacmar K.M. (1992). Perceptions of organizational politics. Journal of Management, Vol. 18, pp. 93-116.

Ferris G. R., Davidson S. L., Perrewe P. L.(2005). Political Skill At Work: Impact on Work Effectiveness. DavisBlack Publishing, Mountain View-California.

Ferris G.R., Treadway D.C., Kolodinsky R.W., Hochwarter W.A., Kacmar C.J., Douglas C., Frink D.D.(2005). Development and validation of the political skill inventory. Journal of Management, Vol.31, 126-152.

Ferris, G. R., Treadway, D. C., Perrewe, P. L., Brouer, R. L., Douglas, C., Lux, S.(2007). Political skill in organizations. Journal of Management, Vol.33, No.3, 290-320.

Goodman, J. M., Evans, W. R., Carson, C. M.(2011). Organizational Politics and Stress: Perceived Accountability as a Coping Mechanism. The Journal of Business Inquiry, Vol.10, No.1, 66-80.

Harris K. J., James M., Boonthanom R. (2005). Perceptions of Organizational Politics and Cooperation as Moderators of the Relationship Between Job Strains and Intent to Turnover. Journal of Management Issues, Vol.17, 26-42.

Harvey, P., Harris, R. B., Harris, K. J., Wheeler, A. R.(2007). Attenuating the Effects of Social Stress: The Impact of Political Skill. Journal of Occupational Health Psychology, Vol.12, No.2, 105-115

Kacmar K. M., Ferris G. R. (1991). Perceptions of organizational politics scale (POPS): Development and construct validation. Educational and Psychological Measurement, Vol.51, pp.193-205. 
Kacmar M. K., Carlson, D. S. (1997). Further validation of the perceptions of politics scale (POPS): A multiple sample investigation.Journal of Management, 23(5), 627-658.

Kacmar K.M., Bozeman D.P., Carlson D.S., Anthony W.P. (1999). An examination of the perceptions of organizational politics model: replication and extension. Human Relations, Vol. 52, 383-416.

Kacmar K.M., Baron R.A. (1999). Organizational politics: the state of the field, links to related processes, and an agenda for future research, Research in Personnel and Human Resources Management, Vol. 17, pp. 1-39.

Karakaya, A., Büyükyılmaz, O., Ay, F. A.(2015). İşyeri Yalnızlı̆̆ının İşkoliklik Üzerindeki Etkisi: Kardemir A.Ş.'de Bir Araştırma, Yönetim ve Ekonomi Araştırmaları Dergisi, Cilt.13, Sayı.3, 79-100.

Kaymaz, K., Eroğlu, U., Sayılar, Y.(2014). Effect f Loneliness at Work on the Employees' Intention to Leave. “iş, GÜÇ" Endüstri illişileri ve İnsan Kaynakları Dergisi, Cilt.16, Sayı.1, 38-53.

Keser A., Karaduman M.(2014). “İ̧̧ Yaşamında Yalnızlık Algısının Örgütsel Vatandaşlık Davranışı İle İlişkisi ve Öğretmenler Üzerinde Bir Araştırma”, HAK-iş Uluslararası Emek ve Toplum Dergisi, Cilt.3, Sayı.7, 179197.

Kimura T. (2013). The Moderating Effects of Political Skill and Leader-Member Exchange on the Relationship Between Organizational Politics and Affective Commitment. Journal of Business Ethics, Vol.116, pp.587-599

Lam, L. W., Lau D. C.(2012). Feeling lonely at work: investigating the consequences of unsatisfactory workplace relationships. The International Journal of Human Resource Management, Vol.23, No.20, 42654282.

Madison D. L., Allen R. W., Porter L. W., Renwick P. A., Mayes B. T. (1980). Organizational politics: An exploration of managers' perceptions, Human Relations, Vol.33, 79-100.

Maslyn J.M., Fedor D.B. (1998). Perceptions of politics: does measuring different foci matter?, Journal of Applied Psychology, Vol. 84, 645-53.

Meisler, G.(2014). Exploring emotional intelligence, political skill, and job satisfaction. Employee Relations, Vol.36, No.3, 280-293.

Meurs, J. A., Gallagher, V. C., Perrewe, P.L.(2010). The role of political skill in the stressor-outcome relationship: Differential predictions for self-and-other reports of political skill. Journal of Vocational Behavior, Vol.76, 520-533.

Munyon, T. P., Summers, J. K., Thompson, K. M., Ferris, G. R.(2015). Political skill and work outcomes: a theoretical extension, meta-analytic investigation, and agenda for the future. Personnel Psychology, Vol.68, 143-184.

Murray V., Gandz J. (2001). Games executives play: Politics at work. Business Horizons, No. 12 (December), pp.11-23.

O'connor W.E., Morrison T.G. (2001). A comparison of situational and dispositional predictors of perceptions of organizational politics, The Journal of Psychology, Vol. 135, 301-312.

Nartgün, Ş.S., Demirer, S.(2016). Öğretmenlerin Örgütsel Sessizlik ille İş Yaşamında Yalnızlık Düzeylerine iliş̧kin Görüşleri. Bayburt Üniversitesi Eğitim Fakültesi, Cilt.7, No.2, 139-156.

Nye L. G.,Witt L. A. (1993). Dimensionality and construct validity of the Perceptions of Organizational Politics Scale. Educational and Psychological Measurement, Vol.53, pp.821-829.

Özçelik, H., Barsade, S.(2011). Work Loneliness and Employee Performance. Academy of Management Annual Meeting Proceedings, Vol.1, 1-6.

Parker C.P., Dipboye R.L., Jackson S.L. (1995). Perceptions of organizational politics: an investigation of antecedents and consequences, Journal of Management, Vol. 21, 891-912.

Peplau, L. A., Perlman, D.(1984). Loneliness Research: A Survey of Empirical Findings. In L. A. Peplau, S. E. Goldston, (Eds.), Preventing The Harmful Consequences of Severe and Persistent Loneliness (pp.1347). Rockville Maryland: National Institute of Mental Health

Perrewe, P. L., Nelson, D. L.(2004). Gender and career success: The facilitative role of political skill. Organizational Dynamics, Vol.33, 366-378.

Pfeffer J.(1999). Güç Merkezli Yönetim: Örgütlerde Politika ve Nüfuz, Boyner Holding Yayınları, İstanbul.

Sarah L. Wright, (2005). Organizational Climate, Social Support and Loneliness in the Workplace. In Neal M. Ashkanasy, Wilfred J. Zerbe, Charmine E.J. Härtel (ed.) The Effect of Affect in Organizational Settings (Research on Emotion in Organizations, Volume 1), Emerald Group Publishing Limited, pp.123 - 142

Stamper, C. L., Masterson, S. S.(2002). Insider or outsider? How employee perceptions of insider status affect their work behavior. Journal of Organizational Behavior, Vol.23, No.8, 875-894. 
Steinburg, A., Sullivan, V., Montoya, L.(1999). Loneliness and social isolation in the workforce for deaf individuals during the transition years: A preliminary investigation. Journal of Applied Rehabilitation Counselling, Vol.30, No.1, 22-30.

Russell, D., Cutrona, C. E., Rose, J., Yurko, K.(1984). Social and Emotional Loneliness: An Examination of Weiss's Typology of Loneliness. Journal of Personality and Social Psychology, Vol.46, No.6, 1313-1321.

Valle M., Perrewe P.L. (2000). Do politics perceptions relate to political behaviors? Tests of an implicit assumption and expanded model, Human Relations, Vol. 53, 359-86.

Vigoda E. (2000). Organizational Politics, Job Attitudes, and Work Outcomes: Exploration and Implications for the Public Sector, Journal of Vocational Behavior, 57(3), 326-347.

Vigoda-Gadot E. (2007). Leadership Style, organizational politics, and employees' performance: An empirical examination of two competing models, Personnel Review, Vol.36, No.5, 661-683.

Voyer J. J.(1994). Coercive Organizational Politics and Organizational Outcomes: An Interpretive Study, Organization Science, Vol.5, No.1, 72-85.

Witt, L. A. (1998). Enhancing organizational goal congruence: A solution to organizational politics, Journal of Applied Psychology, 83(4), 666-674.

Wright, S.L., Burt, C. D.B., Strongman, K.T.(2006). Loneliness in the Workplace: Construct Definition and Scale Development. New Zealand Journal of Psychology, Vol.35, No.2, 59-68.

Yang K. (2008). Examining Perceived Honest Performance Reporting by Public Organizations: Bureaucratic Politics and Organizational Practice, Journal of Public Administration Research and Theory, Vol.19, 81-105. 